TAPROBANICA, ISSN 1800-427X. December, 2013. Vol. 05, No. 02: pp. 151.

(C) Taprobanica Private Limited, 146, Kendalanda, Homagama, Sri Lanka.

http://www.sljol.info/index.php/tapro

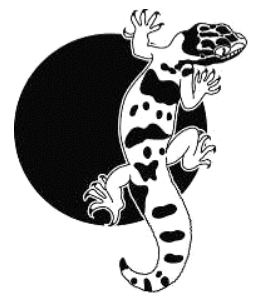

\section{Prey-predator relationship between wolf spider and brachyuran crabs}

Wolf spiders (Arachneae: Lycosidae) are one of the successful hunters which extend their range through various habitats such as wetlands, springs, and sandy coasts (Framenau et al., 2006), though less information is available on their feeding and predatory behaviour. During the course of regular field visits for an ecological study of benthic fauna on the Mahi estuarine mouth at Gulf of Khambhat, on the western coast of India $\left(22^{\circ} 12^{\prime} 59.13^{\prime} \mathrm{N}\right.$, $\left.72^{\circ} 36^{\prime} 55.47^{\prime \prime} \mathrm{E}\right)$, interesting observations about the prey-predation relationship between the wolf spider (Lycos sp.) and two crab species Uca lactea annulipes and Cardisoma carnifex were recorded. The spider species was seen making a burrow (without any webs or ornamentation) in the intertidal mudflat that is dominated with a high density of brachyuran crabs. The burrows dug by the spider (Fig. 1A) mimicked the adjacent burrows of Uca lactea annulipes in the same habitat. In the daytime the wolf spider predates on the crabs using two different strategies. In the first case, the Lycosa $s p$. invaded the crab burrow and actively predated on it. In the second case it adopted a passive method wherein the predator remained in the burrow and waited until a crab entered the burrow. During the night surveys it was observed that another crab species Cardisoma carnifex predated on the spider species (Fig. 1B). Cardisoma carnifex is a carnivore and normally comes out of its burrow for feeding in the night time while in daytime the species mostly buries itself in loose mud. Burrowing amidst the prey's habitat and mimicking the prey's burrow facilitates increased availability of prey in close vicinity. This may be the reason for such unusual occupancy of habitat and behaviour by Lycosa $s p$.

Acknowledgements: We thank Naitik Patel and Mayurdan Gadhvi for field assistance.
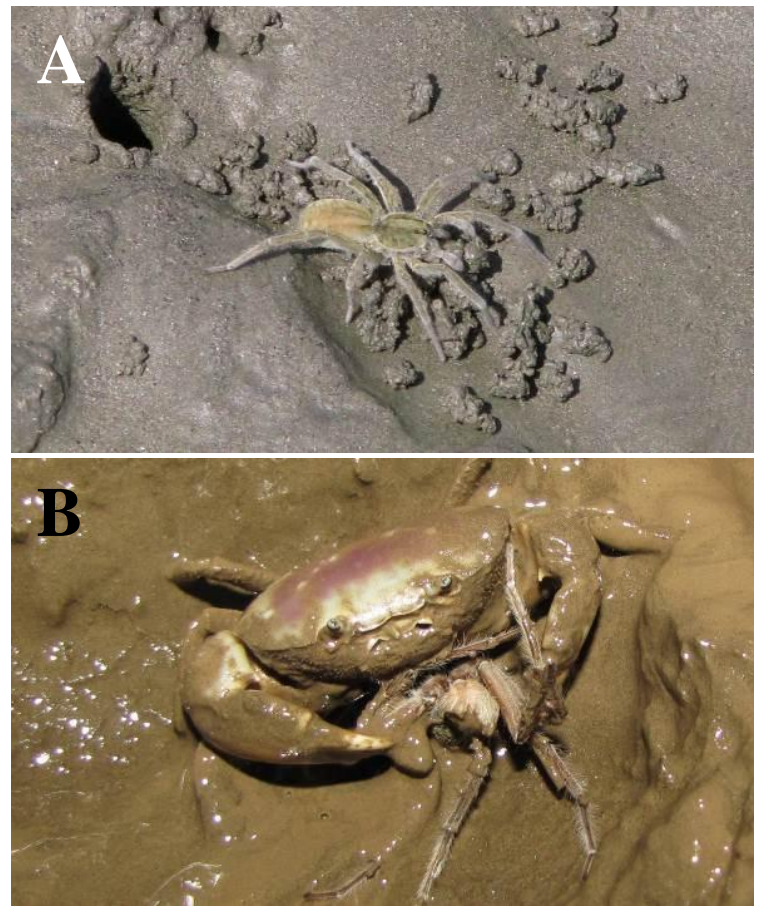

Figure 1: A, A wolf spider is digging a burrow; B, Cardisoma carnifex predation on a wolf spider.

\section{Literature cited:}

Rajashekhar, K. P., and K. P Siju, 2003. Pretending to be a predator: Wasp-like mimicry by a salticid spider. Current Science, 85: 11241135.

Framenau, V. W., T. B. Gotch and A. D. Austin, 2006. The wolf spiders of artesian springs in arid South Australia, with a revalidation of Tetralycosa (Araneae, Lycosidae). The Journal of Arachnology, 34: 136.

Submitted: 3 Nov. 2012, Accepted: 19 Nov. 2013 Sectional Editor: Johanna Bleecker

$$
\begin{array}{r}
\text { P. J. Pandya }{ }^{1} \text {, J. N. Trivedi }{ }^{1} \& \mathrm{~K} . \\
\text { D. Vachhrajani }{ }^{1,2}
\end{array}
$$

${ }^{1}$ Marine Biodiversity and Ecology Lab, Department of Zoology, Faculty of Science, The M. S. University of Baroda, Vadodara, Gujarat, India; E-mail: kauresh@gmail.com² 